\title{
WHAT IS GIVING AID AND COMFORT TO THE ENEMY?

\author{
CHARLES WARREN
} \\ Washington, D. C.
}

The elements of the law of treason are extremely simple, and yet are little understood by laymen, and even by practicing lawyers of the present day. Hence, a critical summary of the principal features of that branch of the crime which consists in giving "aid and comfort". to the enemy may be of assistance during the present trying times. The law in this country on the subject is to be found in very few court decisions, and has been largely laid down in generalities in charges to the grand jury in inferior federal courts. As a result, there has sometimes been a lack of discrimination between the doctrines of law applicable to "levying war" and those applicable to "giving aid and comfort."

Treason is the only crime specifically described in the Constitution. Article III, Section 3, provides:

"Treason against the United States shall consist only in levying war against them, or in adhering to their enemies, giving them aid and comfort. No person shall be convicted of treason unless on the testimony of two witnesses to the same overt act, or on confession in open court."

This definition was based upon the Statute of Treasons of 25 Edward III, ch. 2, in I35I, which comprehended all treasons under seven distinct branches. The framers of our Constitution selected one of these branches and declared that treason against the United States should be confined to the acts which it designated. The Congress can neither enlarge, restrict, nor define the crime; and its power over the subject is limited to prescribing the punishment. ${ }^{x}$

"The word 'only,", said Chief Justice Chase, "was used to exclude from the criminal jurisprudence of the new republic, the odious doctrines of constructive treason. Its use, however, while limiting the definition to plain overt acts, brings these acts into conspicuous relief as being always and in essence treasonable."

The first Congress provided a penalty for the crime of treason by the Act of April 30, I790, ${ }^{3}$ as follows:

${ }^{1}$ United States v. Greathouse (I863, D. C.) 2 Abb. 364, 37r.

'Shortridge v. Macon (1867, C. C. No. Car.) Chase, 136; 22 Fed. Cas. No. I2, 812.

${ }^{8}$ Ch. 9, sec. I, I St. at L. II2.

24 
"That if any person or persons, owing allegiance to the United States of America, shall levy war against them, or shall adhere to their enemies, giving them aid and comfort within the United States or elsewhere, and shall be thereof convicted, on confession in open court, or on the testimony of two witnesses to the same overt act of the treason whereof he or they shall stand indicted, such person or persons shall be adjudged guilty of treason against the United States, and shall suffer death."

This statute became Revised Statutes, Sections 533I, 5332, as follows:

"Sec. 533I. Every person owing allegiance to the United States, who levies war against them, or adheres to their enemies, giving them aid and comfort within the United States or elsewhere, is guilty of treason.

"Sec. 5332. Every person guilty of treason shall suffer death; or, at the discretion of the court, shall be imprisoned at hard labor for not less than five years, and fined not less than ten thousand dollars, to be levied on and collected out of any or all of his property, real and personal, of which he was the owner at the time of committing such treason, any sale or conveyance to the contrary notwithstanding; and every person so convicted of treason shall, moreover, be incapable of holding any office under the United States;"

and is now contained in the Act of March 4, I9094-the Federal Criminal Code-as follows:

"Sec. I. Whoever, owing allegiance to the United States, levies war against them or adheres to their enemies, giving them aid and comfort within the United States or elsewhere, is guilty of treason.

"Sec. 2. Whoever is convicted of treason shall suffer death; or, at the discretion of the court, shall be imprisoned not less than five years and fined not less than ten thousand dollars, to be levied on and collected out of any or all of his property, real and personal, of which he was the owner at the time of committing such treason, any sale or conveyance to the contrary notwithstanding; and every person so convicted of treason shall, moreover, be incapable of holding any office under the United States."

The general principle of construction was laid down by Chief Justice Marshall in r807:

"It is therefore more safe as well as more consonant to the principles of our constitution that the crime of treason should not be extended by construction to doubtful cases; and that crimes not clearly within the constitutional definition, should receive such punishment as the legislature in its wisdom may provide."

The two branches of treason, "levying war," and "adhering to

- Ch. 32I, secs. I and 2, 35 St. at I. I088.

${ }^{8}$ Ex parte Bollman and Swartwout (1807, U. S.) 4 Cranch, 77, I27. 
their enemies, giving them aid and comfort,"--are distinct, and do not embody synonymous actions.

“The term 'enemies,' as used in the second clause, according to its settled meaning, at the time the Constitution was adopted, applies only to the subjects of a foreign power in a state of open hostility with us. It does not embrace rebels in insurrection against their own government."

Hence, treason by levying war is more generally committed in internal insurrections directed against the government by persons in the United States; whereas giving aid and comfort is generally committed in connection with a war waged against the United States by a foreign power. When those who commit treason by levying war become an organized body politic, however, they may become "enemies" within the purview of the law, and giving aid and comfort to such enemies will constitute treason. ${ }^{7}$

The acts constituting giving aid and comfort to the enemy are more numerous and of wider scope than the acts constituting the first branch of the crime, viz., the levying of war. It is important to note this point, for it has been largely disregarded by text-book writers and by judicial authorities (owing probably to the fact that prior to the Civil War every case of treason in the federal courts, with few exceptions, was a case of levying war). As a result of this failure to distinguish between the different elements necessary to constitute the separate branches of the crime, doctrines of law applicable only to levying war have been stated by writers and judges to apply to giving aid and comfort to the enemy. Careful consideration shows, however, that while every action which, when performed by domestic insurrectionaries, will constitute a levying of war, will, when performed in connection with a war with a hostile foreign nation, also constitute a giving of aid and comfort to the enemy, the reverse of this statement is not true. For many actions which give aid and comfort to the enemy are not actions which necessarily constitute a levying of war. Thus, since levying of war consists, in general, of the actual assemblage of men in force, the mere "enlistment of men to serve against the government does not amount to levying war," unless followed up by actual assemblage in force. ${ }^{8}$ But, on the other hand, there can be no possible doubt that the enlistment of men in the United States to serve in the forces of a foreign enemy would constitute giving aid and comfort to the enemy, within the purview of that

\footnotetext{
- See Field, J., in United States v. Greathouse (1863, C. C.) 4 Sawyer, 457, 466, $2 \mathrm{Abb}$. (U. S. D. C.) 364,26 Fed. Cas. No. $15,254$.

${ }^{7}$ Prize Cases (1862, U. S.) a Black, 635 .

- Marshall, C. J., in Ex Parte Bollman and Swartwout (1807, U. S.) 4 Cranch, 75, 126.
} 
branch of the crime of treason; and in the treason statute of Pennsylvania, enacted before the adoption of the United States Constitution, the crime of aiding and assisting the enemy was expressly defined:

"to aid and assist any enemy . . . by joining the armies of the enemy, or by enlisting, or procuring, or persuading others to enlist for that purpose; or by furnishing such enemies with arms or ammunition, provision, or any other article, or articles, for their aid or comfort, or by carrying on a traitorous correspondence with them."?

Other examples of the manner in which giving aid and comfort includes acts of a broader scope than levying war are noted infra.

THE ELEMENTS OF THE CRIME OF "ADHERING TO THEIR ENEMIES, GIVING THEM AID AND COMFORT"

What constitutes giving aid and comfort to the enemy may be described, in general, in the words of Mr. Justice Field:

"The term 'enemies' . . . applies only to the subjects of a foreign power in a state of open hostility with us. . . . Wherever overt acts have been committed which, in their natural consequence, if successful, would encourage and advance the interests of the rebellion, in judgment of law aid and comfort are given. Whether aid and comfort are given-the overt acts of treason being established-is not left to the balancing of probabilities-it is a conclusion of law."10

In the recent Casement treason case in England, in I9I7, on an indictment under the English Treason Act of I35I which reads:

"be adherent to the King's enemies in his realm, giving to them aid and comfort in the realm, or elsewhere," the Lord Chief Justice charged the jury as follows: "If a British subject does an act which strengthens or tends to strengthen the enemies of the King in the conduct of a war against the King, that is in law the giving of aid and comfort to the King's enemies. Again, if a British subject commits an act which weakens or tends to weaken the power of the King and of the country to resist or to attack the enemies of the King and the country, that is in law the giving of aid and comfort to the King's enemies."11

${ }^{\circ}$ Respublica v. Carlisle (1778, U. S.) I Dall. 35, 37; Respublica v. Roberts (I778, U. S.) I Dall. 39; Respublica v. M'Carty (I78r, U. S.) 2 Dall. 86.

${ }^{10}$ Charge to the Grand Jury in United States v. Greathouse (1863, C. C.) 4 Sawyer, 457, 466, 472. These words were quoted with approval by the Supreme Court in Young v. United States (1877) 97 U. S. 39, 65.

The italics above, as well as in the case quoted in note 32 , post, and in the quotations from the cases cited in notes $16,27,33$ and 46 , post, are those of the present writer.

${ }^{11}$ Rex v. Casement [I9I7] I K. B. 98 , I33. 
And Judge Leavitt, in I86I, gave an equally broad definition, saying:

"The words in the definition, adhering to their enemies, seem to have no special significance, as the substance is found in the words which follow-giving them aid and comfort. As before remarked, it is not an easy task to classify or specify the acts, which bring a party within the range of this branch of the definition. In general, when war exists, any act clearly indicating a want of loyalty to the government, and sympathy with its enemies, and which, by fair construction, is directly in furtherance of their hostile designs, gives them aid and comfort." 12

Among the specific acts which have been held to come within the purview of the above are the following:

(a) Selling goods to or buying goods from the enemy government or to or from its agents or forces.

The Supreme Court has said that

"any person owing allegiance to an organized government, can make a contract by which, for the sake of gain, he contributes most substantially and knowingly to the vital necessities of a treasonable conspiracy against its existence, and then in a court of that government base successfully his rights on such a transaction, is opposed to all that we have learned of the invalidity of immoral contracts. A clearer case of turpitude in the consideration of a contract can hardly be imagined unless treason is taken out of the catalogue of crimes.

"The case is not relieved of its harsh features by the firiding of the court that the claimant did not intend to aid the rebellion, but only to make money. It might as well be said that the man who would sell for a sum beyond its value to a lunatic, a weapon with which he knew the latter would kill himself, only intended to make money and did not intend to aid the lunatic in his fatal purpose."

In Young $v$. United States it was held that the words "aid or comfort to the rebellion" as used in the Captured and Abandoned Property Act of March I2, I863, in the Civil War, were used in the same sense as in the Constitution defining treason-"that is to say, in their hostile sense"; and in that case, where a man contracted with the government of the State of North Carolina to provide warlike supplies and to aid in running cotton out through the blockade, and performed acts carrying out his contract, it was held that the acts were clearly treasonable.

Furnishing provisions to public warships of the enemy is treason; ; $^{14}$

${ }^{12}$ Charge to Grand Jury (I86r, C. C.) I Bond, 609, 6II, 30 Fed. Cas. No. 18,372.

"Sprott v. United States (1874, U. S.) 20 Wall. 459, 463; Hanauer v. Doane (I870, U. S.) I2 Wall. 342, 347; Carlisle v. United States (1872, U. S.) I6 Wall. I47, x55; Young v. United States (I877, U. S.) 97 U. S. 39, 64, 65; United States ข. Aaron Burr (1807, U. S.) 4 Cranch, App. 469, 47x.

${ }^{14}$ People v. Lynch (I8I4, N. Y.) II Johns. 549. 
but mere proceeding to shore from a ship with intent to search for or procure provisions for the use of the enemy is not treason..$^{15}$

(b) Communication of intelligence.

Aid and comfort may be furnished to the enemy by giving intelligence, either oral or written, in an attempt to aid him in his acts of hostility. Judge Leavitt, in his Charge to the Grand Jury, in I86r, said:

"Without going into details on the subject, I will briefly notice some things clearly involving the guilt of treason. Thus, to sell to, or provide arms or munitions of war, or military stores, or supplies, including food, clothing, etc., for the use of the enemy, is within the penalty of the statute. And to hire, sell, or furnish boats, railroad cars, or other means of transportation, or to advance money, or obtain credits, for the use and support of a hostile army is treasonable. It is equally clear that the communication of intelligence to the enemy by letter, telegraph, or otherwise, relating to the strength, movements, or position of the army, is an act of treason. These acts, thus briefly noted, show unequivocally an adherence to the enemy, and an unlawful purpose of giving him aid and comfort." ${ }^{\prime \prime 16}$

(c) Joining the enemy in time of war, or offering service by letter.

It is held that joining the enemy is the most flagrant instance of the crime of treason and nothing except the fear of death can excuse it. 13

The writing, uttering and sending of a letter to the President of the Confederate States making an offer of service "was an act of aid and comfort" to the enemy, though the mere writing of a letter, unaccompanied by the sending, uttering or publishing, would not constitute aid and comfort. 18

(d) Delivering up prisoners and deserters to an enemy is treason. ${ }^{19}$

(e) Trade with enemy subjects.

Trade with enemy subjects may, under certain circumstances, be treason. As Mr. Justice Nelson said in a Charge to the Grand Jury in $\mathrm{r} 86 \mathrm{I}$ :

${ }^{25}$ United States v. Pryor (I8I4, C. C.) 3 Wash. 234.

${ }^{16}$ Charge to Grand Jury (I86I, C. C. S. D. Oh.) I Bond, 609, 6II, 30 Fed. Cas.

No. 18,272. See also Respublica v. Carlisle (1778, U. S.) I Dall. 35.

${ }^{17}$ United States v. Greiner (I861, D. C. E. D. Pa.) Fed. Cas. No. 15,262.

${ }^{18}$ Medrway v. United States (1870) $6 \mathrm{Ct}$ Cl. 421, 433. See also Respublica v. $M^{\prime}$ Carty (I78I, U. S.) 2 Dall. 86.

${ }^{10}$ Duval, J., in United States v. Hodges (1815, C. C. D. Md.) 2 Wheel. Cr. 477; 26 Fed. Cas. No. I5,374, held:

"First: The overt act laid consists in the delivery of certain prisoners, and I am of opinion that the overt act laid in the indictment and proved by the witness is high treason against the United States.

"Second: When the act itself amounts to treason it involves the intention, and such was the character of this act." 
"Trade with the enemy . . . according to the law of nations, is forbidden, and, the property engaged in it is liable to forfeiture. . . . The act is not made criminal; and, until it is made so by Congress, no punishment is annexed to it, except the forfeiture of the goods. But, this interdicted trade may be carried on in such a way as to expose the parties concerned to the crime of treason. If carried on for the purpose and with the intent of giving aid and assistance to the enemy in their hostility against the Government, the act would furnish an overt act of adhering to the enemy, giving him aid and comfort. Every citizen, therefore, engaged in carrying on this illicit trade, will find a much greater peril accompanying the enterprise than the mere forfeiture of his goods."20

(f) Acts directed against the government or governmental property with intent to cause injury thereto and in aid of the enemy.

Acts of this description usually amount to "levying war," and therefore generally come within the scope of decisions on the subject of the first clause of the definition of the crime of treason. In reference to this branch of the crime, Mr. Justice Story said in I842:

"It will be equally treason, if the intention is by force to prevent the execution of any one or more general and public laws of the Government, or to resist the exercise of any legitimate authority of the Government in its sovereign capacity. Thus, if there is an assembly of persons with force, with an intent to prevent the collection of the lawful taxes or duties, levied by the Government,-or to destroy all Custom Houses, - or to resist the administration of justice in the Courts of the United States, and they proceed to execute their purpose by force,-there can be no doubt, that it would be treason against the United States."21

But acts of injury to, or destruction of, property of the United States, or property in which the United States has an interest, which property is used or intended to be used for the successful prosecution of the war, may equally constitute treason as giving aid and comfort to the enemy, if the injurious acts are performed with the intent to give or for the purpose of giving, such aid to the enemy in its hostilities against the United States; and, as stated infra, every man must be held to intend the direct, natural and reasonable consequences of his own act.

(g) "Acts which tend and' are designed to defeat, obstruct, or weaken our ozen arms."

The Lord Chief Justice, in the Casement case, said:

"If a British subject does an act which strengthens or tends to strengthen the enemies of the King in the conduct of a war against

${ }^{20}$ Charge to the Grand Jury (I86r, C. C. S. D. N. Y.) 5 Blatch. 549, 552, 30 Fed. Cas. No. I8,27r. See also The Tulip (I812, C. C.) 3 Wash. I8I, I83.

${ }^{21}$ Charge to Grand Jury (1842, C. C.) I Story, 614, 616, 30 Fed. Cas. No. 18,275. 
the King, that is in law the giving of aid and comfort to the King's enemies. Again, . . . to weaken the power of the King and of the country-to resist or to attack the enemies of the King and the country, that is in law the giving of aid and comfort to the King's enemies."22

This would probably include all acts directed to causing insubordination, disloyalty, mutiny, or refusal of duty in the military or naval forces of the United States, or obstructing the recruiting or enlistment service or the operation of draft laws.

(h) Acts which, if performed by domestic insurrectionaries, would constitute levying of war, may equally constitute giving aid and comfort to the enemy if performed in connection with or for the assistance of a foreign enemy waging war against the United States.

Two elements must always be present to constitute a levying of war: (I) actual assemblage of an armed force, or of a force sufficient to intimidate by numbers; (2) intent to overthrow the government or to prevent the enforcement in general of one of its laws. As Mr. Justice Patterson, in one of the earliest treason cases, said in substance: To resist or prevent by armed force and intimidation the execution of a general act of the United States is a levying of war against the United States. ${ }^{23}$ This was made more precise by Marshall in the Burr case:

"War can only be levied by the employment of actual force. Troops must be embodied, men must be assembled, in order to levy war."

And again, in another phase of the Burr case, Marshall amplified this :

"It is necessary to show the assemblage in order to substantiate the two important elements, first of intent, and, secondly, of ability to carry out the crime. That is to say, that if the intent were not shown and if there were not a sufficient body of people together assembled to make it clear that they had the ability to carry out such an intent the conspiracy could not amount to treason. . . . All those who perform the various and essential military parts of prosecuting the war, which must be assigned to different persons, may with correctness and accuracy be said to levy war."25

And, speaking for the Supreme Court in United States v. Bollman and Swartwout, Marshall said:

${ }^{22}$ Rex v. Casement [I9I7] I K. B. 98, 133. And see Sprague, J., in Charge to Grand Jury (I86r, C. C.) 2 Sprague, 285, 30 Fed. Cas. No. 18,277.

${ }^{2}$ United States v. Mitchell (1795, C. C.) 2 Dall. 348. See United States $v$. Vigol (1795, C. C.) 2 Dall. 346. See also opinions of Iredell, J., Chase, J., and Peters, D. J., in the Fries Case (1799, C. C.) Whart. St. Tr. 458, 3 Dall. 505, Fed. Cas. No. 5I26, pp. 840, 909.

24 United States v. Aaron Burr, Fed. Cas. No. 14,692a, p. I3.

${ }^{25}$ Idem. Fed. Cas. No. 14,693, p. I6r. 
"It is not the intention of the court to say that no individual can be guilty of this crime who has not prepared in arms against his country. On the contrary, if war be actually levied, that is, if a body of men be actually assembled for the purpose of effecting by force a treasonable purpose, all those who perform any part, however minute, or however remote from the scene of action, and who are actually leagued in the general conspiracy, are to be considered as traitors. But there must be an actual assembling of men, for the treasonable purpose, to constitute a levying of war." ${ }^{\prime 26}$

This doctrine was later summed up by Mr. Justice Story, in I842, as follows:

"To constitute an actual levy of war, there must be an assembly of persons, met for the treasonable purpose, and some overt act done, or some attempt made by them with force to execute, or towards executing, that purpose. There must be a present intention to proceed in the execution of the treasonable purpose by force. The assembly must now be in a condition to use force, and must intend to use it, if necessary, to further, or to aid, or to accomplish the treasonable design."27

The conspiracy and insurrection connected with it must be to effect something of a public nature, to overthrow the government, or to nullify some law of the United States, and totally to hinder its execution or compel its repeal. ${ }^{28}$

In an able article on The Law of Treason, Professor Simon Greenleaf, in $185 \mathrm{I}$, speaking of the purpose

"to resist the execution of a law of the United States; not in a particular instance or case alone, but in pursuance of a determination to prevent its operation at all, in any and every case," says: "Wherever a body of men are assembled in force for such a purpose, and are in a condition to carry that purpose into effect, the assemblage itself is an act of levying war." ${ }^{\prime 2}$

If there be an actual assemblage for the above purposes, it is not necessary that actual acts of violence should take place in order to make the assemblage treasonable.

"When a body, large or small, of armed men, is mustered in military array for a treasonable purpose, every step which any one of them

${ }^{2}$ (1807) 4 Cranch, 75, 126.

${ }^{27}$ Charge to Grand Jury (1842, C. C.) 30 Fed. Cas. No. $18,275$.

${ }^{\infty}$ Grier, J., in United States v. Hastway (185I, C. C. E. D. Pa.). 2 Wall. Jr. I39, 26 Fed. Cas. No. 15,299, p. 128. See also Druecker v. Salomon (1867) 2r Wis. 621. See esp. Curtis, J., in Charge to Grand Jury (I86I, C. C. D. Mass.) 30 Fed. Cas. No. 18,269; United States v. Hoxie (1808, C. C. D. Vt) I Paine C. C. 265 , Fed. Cas. No. 15,407 .

27 (December, I85I) I4 Monthly Law RepoRter, 409, 416. 
takes in part execution of this purpose, is an overt act of levying war. This is true, though not a warlike blow may have been struck."30

(i) Advising, inciting and persuading others to give aid and comfort to the enemy may in itself constitute treason.

"Mere expressions of opinion," said Judge Leavitt in his Charge to the Grand Jury in I86I, "indicative of sympathy with the public enemy will not ordinarily involve the legal guilt of that crime."31

Nevertheless, the speaking or writing of words may in itself be an act of such a nature as to constitute treason. Thus, while words which merely express a man's opinions or statements of intentions may not be treason, words which embody advice, or counsel, or inducement, or persuasion, to others to commit any of the acts recited in subdivisions (a), (b), (c), (d), (e), (f), (g), (h), supra, may constitute in themselves the act of advising, counselling, inducing, or persuading, which act may in itself be a treasonable act; and the embodiment of such words in circulars, or other printed matter, and their circulation or distribution may be treasonable acts. "Inciting or encouraging others" to aid the enemy, even if such incitement or encouragement is merely verbal, may constitute very substantial acts of aid and comfort. ${ }^{32}$

In the Casement case, in which the defendant was indicted for giving aid and comfort to the enemy, one of the overt acts alleged was as follows:

"Of soliciting and inciting and endeavouring to persuade certain persons being British subjects and members of the military forces of the King and being prisoners of war . . . to forsake their duty and allegiance to the King and to join the armed forces of his enemies

so United States v. Greiner (186r, D. C. E. D. Pa.) Fed. Cas. No. 15,262, p. 39. An article on Treason written prior to the Burr case is to be found in (I808) I AM. LAW J. 344, 359, which takes the opposite view, and contends :

"Laying, therefore, the opinion of the supreme court out of the case, I hold it to be clear and settled law, that the actual employment of the force, after it has been assembled, in some unlawful act of violence conducive to the accomplishment of the hostile design, is necessary to constitute the crime of levying war." See Curtis, J., in Charge to Grand Jury (185I) Fed. Cas. No. I8,269.

"Charge to Grand Jury (I86I, C. C. S. D. Oh.) I Bond, 609, 30 Fed. Cas. No. 18,272. See also Mr. Justice Nelson, in Charge to Grand Jury (I86r, C. C. S. D. N. Y.) 5 Blatch. 549, 30 Fed. Cas. No. 18,271.

Judge Smalley in Charge to Grand Jury (r86I, U. S. D. C. S. D. N. Y.) 4 Blatch. 518, Fed. Cas. No. 18,270, states :

"What amounts to adhering to, and giving aid and comfort to our enemies, it is somewhat difficult in all cases to define; but certain it is, that furnishing them with arms or munitions of war, vessels or other means of transportation, or any materials which will aid the traitors in carrying out their traitorous purposes, with a knowledge that they are intended for such purposes, or inciting and encouraging others to engage in or aid the traitors in any way, does come within the provisions of the act."

(The word "traitors" in the above charge is synonymous with "enemies.") 
and to fight against the King. ...." Another overt act was "circulating and distributing and causing and procuring to be circulated and distributed to and amongst certain persons being British subjects and members of the military forces of the King and being prisoners of war. . . a certain leaflet . . . with intent to solicit, incite, and persuade the said last-mentioned British subjects, being Irishmen, to forsake their duty and allegiance to the King and to aid and assist his enemiès in the prosecution of the said war against the King and his subjects." 33

Of course, it may be difficult to draw the line between treasonable incitement and legitimate expressions of views and propaganda. The circumstances in each case must control, and it must be remembered that a course of conduct or acts, under modern conditions, may render vital aid and comfort to the enemy, where similar conduct or acts would not have done so in earlier days. As has been well said in a recent thoughtful pamphlet on this topic:

"In simpler times-only a comparatively few. years ago-when daily printing of information and news was unknown, when cables and wireless did not convey what is written, done and spoken to the four quarters of the world on the instant, such cases as, in view of modern conditions, might well arise today under the law of treason were naturally unknown. But we are'concerned with today, not yesterday, and must expect modern acts to be adjudged in accord with modern conditions. - . A A persisting series of speeches or written or printed articles or editorials conveying, when taken in the mass, information which might be reasonably deemed to be of assistance to the military endeavors of the enemy, or consisting of statements either true or false of existing or of claimed conditions or facts the knowledge of or belief in truth of which, by encouraging would tend to increase his resistance, or by discouraging would tend to diminish the effective of the United States, would be sufficient foundation for a finding both of adherence to the enemy and of giving of aid and comfort. In other words, the cumulative effect of such a series of addresses or articles would, within the rules of law, be held to afford suitable foundation for a finding by a jury that the accused not only adhered to the enemy, but gave them aid and comfort." 34

It is clear, however, that plotting and scheming and conferring of persons having traitorious designs-mere conspiracy-cannot constitute treason unless the plot or private conference is followed by some step to put the treasonable design into effect. Such a mere conspiracy is now punishable as a separate crime known as seditious conspiracy, under Section 6 of the Federal Penal Code.

With reference to that branch of treason which consists in levying war, it is a more doubtful question, much discussed in the courts in early days, whether the advising or inciting others to levy war can ever constitute a levying of war itself. The point still remains unde-

[ror5] I K. B. 98, 99 .

Pamphlet by Charles Stewart Davison, Treason (Aug. 24, I9I7). 
termined by any express adjudication. ${ }^{35}$ Mr. Justice Curtis, however, in a Charge to the Grand Jury in I85x, stated that if the levying of war actually occurred through assemblage of men, then

"they who have the wickedness to plan and incite and aid, and who perform any part however minute, are justly deemed guilty of this offence, though they are not present at the immediate scene of violence." 36 And he stated further: "Influential persons cannot form associations to resist the law by violence, excite the passion of ignorant and unreflecting, or desperate men, incite them to action, supply them with weapons, and then retire and await in safety the result of the violence which they themselves have caused. To permit this, would not only be inconsistent with sound policy, but without a due regard to the just responsibilities of men. The law does not permit it."’at

If the person is present during the actual perpetration of the levying of war, and is countenancing, encouraging, aiding, counselling or abetting the actual perpetration, he is clearly guilty of treason. ${ }^{38}$

On the other hand, it is equally clear that a mere conspiracy to levy war, not followed by any actual levying of war, does not constitute the crime of treason itself ; $; 9$ for, as Marshall said :

"However flagitious may be the crime of conspiring to subvert by force the government of our country, such conspiracy is not treason. To conspire to levy war, and actually to levy war, are distinct offences. The first must be brought into operation by the assemblage of men

${ }^{25}$ See United States v. Aaron Burr (1807) Fed. Cas. No. I4,693, Note A, p. 18r. Marshall, C. J., in the Burr case expressly declined to pass upon it (ibid. p. I6r).

(C. C. D. Mass.) Fed. Cas. No. 18,269, p. 1026.

"So Kane, J., in Charge to Grand Jury (I85I, C. C. E. D. Pa.) 30 Fed. Cas. No. 18,276 , held in case of "levying war" that if forcible acts had been committed,

"If he was present, directing, aiding, abetting, counselling, or countenancing it, he is in law guilty of the forcible act. Nor is even his personal presence indispensable. Though he be absent at the time of its actual perpetration, yet if he directed the act, devised or knowingly furnished the means, for carrying it into effect, instigating others to perform it, he shares their guilt."

The same doctrine is vigorously upheld by Professor Simon Greenleaf, On the Law of Treason (I85I) I4 LAW REP. 409. As to Judge Kane's charge, Note A in the Burr case, 25 Fed. Cas. No. 14,693, p. 182, says :

"These mere obiter dicta of a district judge, thrown out in a charge to the grand jury, derive their only consequence from the fact that Judge Grier, subsequently in his charge to the petit jury in Hanway's case expressed his general concurrence in the doctrines and sentiments of said charge to the grand jury delivered by Judge Kane. But, as has been before stated, there was nothing in Hanway's case to call for any opinion on the question now under consideration. -...

${ }^{*}$ Grier, J., in United States v. Hanway (I85I, C. C. E. D. Pa.) 2 Wall. Jr. 139, . 26 Fed. Cas. No. 15,299 , p. 126.

${ }^{89}$ United States v. Hoxie (1808, C. C. D. Vt.) I Paine, 265, 26 Fed. Cas. No. 15,407; Nelson, J., in Charge to Grand Jury (I86r, C. C. S. D. N. Y.) 30 Fed. Cas. No. I8,27r; United States v. Hanway (I85I, C. C. E. D. Pa.) 2 Wall. Jr. 139, 26 Fed. Cas. No. I5,299; United States v. Burr (I807) 25 Fed. Cas. No. I4,692a, p. 14, 4 Cranch, App. 469; United States v. Pryor (1814, C. C. D. Pa.) 27 Fed. Cas. No. 16,096. 
for a purpose treasonable in itself, or the fact of levying war cannot have been committed. . . ."\$0

\section{OVERT ACT}

There must be an overt act, for it is well settled that the law cannot punish a mere operation of the mind. The words "overt act" mean an act of a character susceptible of clear proof and not resting in mere inference or conjecture. An "overt act," however, can be as well words as deeds if they can be proved by direct evidence. The requirement of proof of an "overt act," it has been said, was intended to exclude the possibility of a conviction of the odious crime of treason upon proof of facts which may be only treasonable by construction or inference, or which have no better foundation than mere suspicion. ${ }^{41}$

Where the overt act is a composite thing, made up of several circumstances, and passing through various stages, it is not necessary, in order to satisfy the provisions of the statute requiring two witnesses to an overt act, that there should be two witnesses to each circumstance at each stage. 2

Conviction of treason cannot be had on confession, unless such confession is in open coutt. But evidence of confession out of court is admissible to corroborate evidence of overt acts. ${ }^{43}$

\section{INTENT}

There must be intent to commit the crime. This, however, does not mean that the intent described as a constituent element of the crime may not be deemed to exist unless the accused can be proved to have had an actual mental purpose to commit the crime of treason, as described in the Constitution and the statutes enacted for its punishment. It does not mean that if the accused had the design to perform some specific act, but did not specifically intend to commit the crime of treason, such act may not be properly considered as within the definition of the crime.

In that branch of the crime of treason which consists in giving aid and comfort to the enemy, the act itself, in most instances, may prove ipso facto the intent; and, as was stated by Mr. Justice Duval: "When the act itself amounts to treason, it involves the intention, and such was the character of this act" (in that case the act being delivery to

\footnotetext{
"Ex Parte Bollman and Swartwout (I807, U. S.) 4 Cranch, 75, 126.

a Charge to Grand Jury (I86r, C. C. S. D. Oh.) I Bond, 609, 30 Fed. Cas. No. I8,372.

【United States v. Mitchell (I795, C. C. D. Pa.) 2 Dall. 348; Regina v. McCafferty (I867) no Cox Cr. 603.

- Respublica v. Roberts (I778) I Dall. 39; Respublica v. M'Carty (I78I) 2 Dall. 86; United States v. Lee (I8r4, C. C. D. Col.) 26 Fed. Cas. No. 15,584.
} 
the enemy of certain prisoners)..$^{44}$ If, therefore, a person intends to do and actually does specific acts the natural and probable consequences . of which are the giving of aid and comfort to the enemy, then he intends to commit treason, within the purview of the law. The purpose or motive of the act is not essential.

As the Supreme Court said, as we have seen, in Sprott v. United States:

"The case is not relieved of its harsh features by the finding of the court that the claimant did not intend to aid the rebellion, but only to make money. It might as well be said that the man who would sell for a sum beyond its value to a lunatic, a weapon with which he knew the latter would kill himself, only intended to make money and did not intend to aid the lunatic in his fatal purpose."45

\section{And again, in Hanauer v. Doane:}

"No crime is greater than treason. He who, being bound by his allegiance to a government, sells goods to the agent of an armed combination to overthrow that government, knowing that the purchaser buys them for that treasonable purpose, is himself guilty of treason or a misprision thereof. He voluntarily aids the treason. He cannot be permitted to stand on the nice metaphysical distinction that, although he knows that the purchaser buys the goods for the purpose of aiding the rebellion, he does not sell them for that purpose. The consequences of his acts are too serious and enormous to admit of such a plea. He must be taken to intend the consequences of his owem voluntary act."16

Every man is presumed to intend the necessary and legitimate consequences of his acts. The rule was laid down in Reynold's $v$. United States as follows:

"A criminal intent is generally an element of crime, but every man is presumed to intend the necessary and legitimate consequences of what he knowingly does." ${ }^{\text {47 }}$

And by Chief Justice Shaw in the famous Webster murder case in a most lucid manner:

"This rule is founded on the plain and obvious principle, that a person must be presumed to intend to do that which he voluntarily and wilfully does in fact do, and that he must intend all the natural, probable, and usual consequences of his own acts ... The ordinary feelings, passions, and propensities under which parties act, are facts

"United States v. Hodges (18r5, C. C. D. Md.) 2 Wheel. Cr. 477, 26 Fed. Cas. No. I5,374.

45 (I874, U. S.) 20 Wall. $459,463$.

(1874, U. S.) I2 Wall. 342, 347. See also Leavitt, J., in Charge to Grand Jury (186I) I Bond, 609, 30 Fed. Cas. No. 18,272:

"If this be the natural effect of the act, though prompted solely by the expectation of pecuniary gain, it is treasonable in its character."

$"$ (I878) 98 U. S. I45, 167; United States v. Patten (I9I3) 226 U. S. 525, 543. 
known by observation and experience; and they are so tuniform in their operation, that a conclusion may be safely drawn, that if a person acts in a particular manner he does so under the influence of a particular motive. Indeed, this is the only mode in which a large class of crimes can be proved. I mean crimes, which consist not merely in an act done, but in the motive and intent with which they are done. But this intent is a secret of the heart, which can only be directly known to the searcher of all hearts; and if the accused makes no declaration on the subject, and chooses to keep his own secret, which he is likely to do if his purposes are criminal, such criminal intent may be inferred, and often is safely inferred, from his conduct and external acts." 48

Although the Constitution requires two witnesses to the same overt act to prove treason, two witnesses are not required to prove the intention. ${ }^{40}$ This may be established by the declarations of the party prior to or during the commission of the treasonable acts, or the same may be established by the prisoner's conduct in other places. As was said in the Burr case:

"The conduct of a prisoner at other places and times tends to show the intent with which the overt act is committed and his acts at those places can be introduced as evidence of the treasonable design, although the prisoner is not on trial for such offense and is not punishable therefor, as all the acts are caused by one general design."

And it is further said that since the intent or design is a hidden or obscure mental act, all evidence of its outward expression is admissible. $^{51}$ How far this doctrine is carried out is shown in the case of Sprott v. United States, ${ }^{52}$ where there was a specific finding of the trial court that the claimant did not intend to aid the rebellion in purchasing three hundred bales of cotton from an agent of the Confederate States, but as to which the Court replied as cited supra.

\section{SUCCESSFUL CARRYING OUT OF TREASONABLE ACT}

To constitute treason, it is not necessary that the treasonable act should have been successfully performed. The leading decision on this subject is by Mr. Justice Field in United States $v$. Greathouse. ${ }^{53}$ In that case the defendant was indicted for purchasing a vessel, guns and ammunition; getting her ready for sea and preparing her for service in aid of the rebellion against the United States after the levy

* Commonwealth v. Webster (I850, Mass.) 5 Cush. 295, 305, 316. See also United States v. Hoxie (1808, C. C. Vt.) I Paine, 265, 280; Charge to Grand Jury (1842) I Story, 614; United States v. Bollman (1806) I Cranch, 373, 384.

- United States v. Fries, supra.

${ }^{\circ}$ United States v. Burr, 25 Fed. Cas. No. 14,693.

anited States v. Fries, supra.

$\approx$ (I874, U. S.) 20 Wall. 459.

(I863, C. C. D. Cal.) 2 Abb. $364,379$. 
of war with the purpose of attacking and destroying the United States vessels. These were held to be overt acts of treason as giving aid and comfort to the enemy; and it was said:

"It is not essential, to constitute the giving of aid and comfort, that the enterprise commenced should be successful, and actually render assistance. If, for example, a vessel fully equipped and armed in the service of the rebellion should fail in its attack upon one of our vessels, and be itself captured, no assistance would, in truth, be rendered to the rebellion; but yet, in judgment of law-in legal intent-the aid and comfort would be given. So if a letter containing important intelligence for the insurgents, be forwarded, the aid and comfort are given, though the letter be intercepted on its way. Thus, Foster, in his Treatise on Crown Law, says: 'And the bare sending money or provisions, or sending intelligence to rebels or enemies, which in most cases is the most effectual aid that can be given them, will make a man a traitor, though the money or intelligence should happen to be intercepted; for the party in sending it did all he could; the treason was complete on his part, though it had not the effect he intended."

So, also, in case of letters to the enemy which are intercepted and never reach the enemy, it is held that the treason is complete on the defendant's part, in that he has done all that he can to carry it forward. As was said by Lord Chief Justice Kenyon:

"Letters of advice and correspondence and intelligence to the enemy, to enable them to annoy us or to defend themselves, written and sent in order to be delivered to the enemy, are, though intercepted, overt acts of both these species of treason [levying war and giving aid and comfort]."154

That treason may be committed by aliens as well as by citizens is not generally understood by laymen. It is clearly established, however, in the law. The theory underlying this crime and its punishment is that every individual owes fidelity and allegiance to the government under which he is living, in return for the protection which he receives from that government. The citizen or subject owes an absolute and permanent allegiance to his government or sovereign, or, at least, until by some open and distinct act he renounces it and becomes a citizen or subject of another government or another sovereign. The alien whilst domiciled in the country owes a local and temporary allegiance which continues during the period of his residence; and this alien or stranger born, for so long a time as he continues within the dominions of the foreign government, may be punished for treason.

In Carlisle v. United States ${ }^{55}$ - a leading authority-Mr. Justice Field stated the doctrine as follows:

\footnotetext{
${ }^{*}$ Rex $v$. Stone (I796) 6 Term Rep. 527, 529. To the same effect are Rex $v$. Hensey (I758) I Burr. 642, and Gregg's Trial (1708) I4 How. St. Tr. I37r.

(I872, U. S.) I6 Wall. I47, 155. See also Radich v. Hutchins (1877) 95 U. S. 210, United States v. Wiltberger (I820, U. S.) 5 Wheaton, 76.
} 


\section{ADDENDA}

[Through editorial oversight, the concluding portion of the article on What Is Giving Aid and Comfort to the Enemy? by Charles Warren, Esq., was omitted from the January issue. This portion is printed below. The present sheet should be bound after page $346 .-E d$.

MEANING OF "AID AND COMFORT" AS USED IN OTHER STATUTES

There have been various federal statutes other than the Treason Act in which the words "aid and comfort" to the enemy have been used and construed by the courts, - see the Abandoned and Captured Property Act of March 3[12], I863, ${ }^{56}$ the Court of Claims Act of June 25, $1868 .^{57}$ Decisions of the Court of Claims may be somewhat helpful in ascertaining the meaning of these words, although those decisions (prior to 1870) are not an entirely safe precedent; for that court in holding, in I866, that they included "any acts voluntarily committed which would tend to assist, countenance, abet, or encourage the rebellion," also held that the words were not confined "to such acts as would under the Constitution and laws constitute treason." ${ }^{28}$ If this expression simply meant that which was decided in the Supreme Court in I87o in Young v. United States, ${ }^{59}$ viz.: that "a claimant to be excluded need not have been a traitor: it is sufficient if he has done that which would have made him a traitor if he had owed allegiance to the United States," then the Court of Claims cases are of value. The following acts, among others, have been held to constitute "aid and comfort": standing guard over Federal prisoners and being enrolled for local defense in Richmond; intending enemy boats, and running through the federal blockade, engaging in commercial transactions within the enemy lines; ${ }^{81}$ connection with blockade companies and violations of blockade law; ${ }^{62}$ bringing slaves within the Confederate lines to prevent their emancipation $;^{63}$ allowing a steamboat to be used in the military service of the

${ }^{56} \mathrm{Ch} .120$, I2 St. at L. 820.

${ }^{87} \mathrm{Ch} .71$, sec. 3, I5 St. at L. 75 .

The Diplomatic Protection of Citizens Abroad (1915) by Edwin M. Borchard, pp. 786 et seq. contains a valuable compilation of decisions and findings construing the words "aid and comfort" by the Court of Claims and by international arbitration and other boards and commissions.

Bond v. United Statcs (I866) 2 Ct. Cl. 529, 533; Wylie v. United States

(I870) 6 Ct. Cl. 295, 300; Collie v. United States (1873) 9 Ct. Cl. 43I, 452;

(I876) I2 Ct. Cl: $648,685,699 ; 97$ U. S. 39.

(I877) 97 U. S. 39, 62.

- Kuper v. United States (1867) 3 Ct. Cl. 74.

" Gearing v. United States (1867) 3 Ct. C1. 165, 172.

"Bates' Case (1868) 4 Ct Cl. 569.

*Armstrong v. United States (1869) 5 Ct. Cl. 623-see (1872, U. S.) I3 Wall. 154 
enemy. ${ }^{64}$ In Grossmeyer v. United States" it is said: "To constitute them [aid and comfort] such they must have been committed with the intention and for the purpose of aiding the rebellion, and promoting its power and success, or from other improper motives." It is not sufficient to prove a purpose to give aid and comfort; the actual fact of the giving of such aid is necessary to be proved. ${ }^{66}$

\section{GENERAL CONSIDERATION}

Criminal statutes serve their purpose, of course, only so far as they tend to prevent crime and to secure the punishment of violators of law. Because of the limitations imposed by the Constitution and by the federal statutes upon the crime of treason and its proof, because of the heavy penalties and the odium attached to the crime, and because of the disinclination of courts to rule and of juries to indict and to find that treason has been committed, except in cases which present extreme facts, Congress has at very various periods of our history found it desirable to enact special statutes making penal certain classes of acts which might already come within the purview of acts of treason. Illustrations of such statutes may be found in recent legislation. See Title I relating to Espionage of the Act of June 15, I9I7, and certain provisions of the Trading with the Enemy Act of October 6, I9I7. The performance of one act may constitute a violation of more than one criminal statute, and a person may, in fact, be guilty of committing treason, even though prosecuted and convicted for a violation of a statute constituting a lesser degree of crime; therefore, whether a person shall be prosecuted under one of these special statutes or under the treason statute is a question of practical administration of the law. Finally, it may be pointed out that no man, even from motives of religion or other fundamental belief, may render aid and comfort to the enemy without being liable to conviction of treason if the legal proof be forthcoming and if the jury does its duty. As the court well said in Culliton v. United States ${ }^{67}$ in 1869 :

"It [the proclamation of war] forms the dividing line. . . . Before hostilities began, many loyal persons, North as [well as] South, believed that a separation, reluctantly consented to, would be peacefully accomplished. When the reality of war came, there was no ground left for either hope or equivocation. The duty of the citizen then became as clear as imperative; men became eo instanti loyal or disloyal. As thunderstorms are commonly supposed to clear the atmosphere, so the reverberations of . . guns cleared away hopes and doubts, and left every citizen either the friend or the enemy of the nation."

Slawson's Case (1870) $6 \mathrm{Ct} . \mathrm{Cl} .370$, (I873, U. S.) x6 Wall. 310.

(I868) 4 Ct. Cl. I, I3.

${ }^{\circ}$ Hill v. United States (1872) $8 \mathrm{Ct}$ Cl. 470.

${ }^{\circ}{ }_{5} \mathrm{Ct} . \mathrm{Cl} .627,63 \mathrm{I}$. 
" 'Every foreigner born residing in a country owes to that country allegiance and obedience to its laws so long as he remains in it, as a duty upon him by the mere fact of his residence, and that temporary protection which he enjoys, and is as much bound to obey its laws, as native subjects or citizens. This is the universal understanding in all civilized states, and nowhere a more established doctrine than in this country. Independently of a residence with intention to continue such residence; independently of any domiciliation; independently of the taking of any oath of allegiance or of renouncing any former allegiance, it is well known that by the public law an alien or a stranger born, for so long a time as he continues within the dominions of a foreign government, owes obedience to the laws of that government, and may be punished for treason or other crimes as a native-born subject might be, unless his case is varied by some treaty stipulation."

All aliens, therefore, in the United States who in any way give aid and comfort to the enemy, even though that enemy be of their own blood and kin, are guilty of treason to the United States, and may be punished by death, exactly as any citizen native born or naturalized who performs the same acts may suffer that penalty. 